\title{
Gambaran Pengetahuan, Sikap, dan Praktik Perilaku Mahasiswa terhadap HIV/AIDS dan ODHA (Orang dengan HIV/AIDS)
}

\section{(Overview of Knowledge, Attitude, and Practices of Student Behavior towards HIV / AIDS and PLWHA (People Living with HIV / AIDS)}

\author{
BONA S. H. HUTAHAEAN \\ Fakultas Psikologi, Universitas Indonesia \\ Email: bonasardo@ui.ac.id ${ }^{1}$
}

Diterima 3 April 2017, Disetujui 5 Juni 2017

\begin{abstract}
Abstrak: Mahasiswa sarjana pada masa remaja dan dewasa muda sudah produktif secara seksual. Sangat penting untuk mengetahui gambaran pengetahuan, sikap, dan praktik (KAP) mereka terhadap HIV/AIDS karena infeksi HIV tertinggi di Indonesia hingga tahun 2016 terjadi pada usia remaja dan dewasa muda. Survei ini dilakukan di Indonesia antara November-Desember 2015. Data dikumpulkan menggunakan kuesioner KAP terstruktur secara online pada 350 mahasiswa sarjana (berusia 18-23 tahun) di Universitas Indonesia dan dianalisis dengan statistik deskriptif. Kuesioner yang digunakan diadaptasi dari kuesioner KAP Mulu, Abera, dan Yimer (2014). Hasil survei menunjukkan bahwa sebagian besar partisipan menjawab aitem pengetahuan dengan benar, tetapi kebanyakan dari mereka masih tidak tahu bahwa HIV dan AIDS adalah dua hal yang berbeda, dan mereka berpikir bahwa HIV dapat terinfeksi melalui berbagi makanan, bertukar pakaian dan toilet dengan ODHA (Orang dengan HIV dan AIDS). Sebagian besar peserta memiliki sikap positif terhadap HIV/AIDS, tetapi mereka memiliki sikap negatif mengenai penggunaan kondom saat berhubungan seks yang dianggap sebagai penghinaan terhadap pasangan, dan tidak setuju untuk hidup bersama dengan ODHA. Mengenai praktiknya, sebanyak 76 peserta yang pernah melakukan hubungan seks pernah memiliki perilaku seksual berisiko, tetapi tidak pernah melakukan VCT (Voluntary Counseling \& Testing), sedangkan peserta lainnya yang tidak pernah melakukan hubungan seks kebanyakan telah melihat kondom tetapi tidak merasa nyaman untuk memegangnya. Pengetahuan tentang HIV/AIDS cukup memadai, sikapnya cukup adil, tetapi praktik bagi para partisipan yang pernah berhubungan seks membutuhkan lebih banyak perhatian. Hasil survei ini juga mungkin menunjukkan stigma terhadap HIV/AIDS di Indonesia masih ada karena HIV dianggap sebagai penyakit yang mudah terinfeksi.
\end{abstract}

Kata kunci: HIV/AIDS; mahasiswa sarjana; pengetahuan; sikap, praktik

Abstract: Undergraduate students in adolescence and young adulthood period are sexually productive. It is crucial to discover their knowledge, attitude, and practice (KAP) towards HIV/AIDS since the highest HIV infection in Indonesia until 2016 is between those ages. The survey was conducted in Indonesia between November-December 2015. Data was collected using online structured KAP questionnaire to 350 undergraduate students (aged 18-23 years old) in Universitas Indonesia and analyzed with descriptive statistic. The KAP questionnaire used was adapted from Mulu, Abera, and Yimer (2014). Results shown that most participants answered correctly in knowledge items, but most of them still didn't know that HIV and AIDS are two different things, and they think that HIV can be infected through sharing foods, exchanging clothes and toilets with PLWH (People Living with HIV). Most participants have a positive attitude towards HIVIAIDS, but they have a negative attitude regarding on using condom while having sex as an affront to the couple, and disagreeing to live together with PLWH. Regarding on the practice, as much as 76 participants who have had sex ever had a risky sexual behavior but never had VCT (Voluntary Counseling \& Testing), while the rest of participants who never had sex mostly have seen a condom but didn't feel comfortable to hold it. Knowledge towards HIV/AIDS was quite sufficient, the attitude was fair enough, but the practice for the participants who have had sex needed attention more. The result also might indicate stigma towards HIV/AIDS in Indonesia still exists because HIV is considered as an easily infected disease.

Keywords: HIV/AIDS; undergraduate students; KAP (knowledge, attitude, practice) 


\section{PENDAHULUAN}

HIV (Human Immunodeficiency Virus) merupakan virus yang ditularkan melalui cairan semen atau darah, kemudian menyerang sistem kekebalan tubuh yang terinfeksi sehingga manusia semakin mudah terserang penyakit (Sarafino, 1998). Lebih lanjut, Sarafino (1998) menjelaskan apabila virus ini semakin lama berada dalam tubuh manusia dan tidak ditangani dengan segera, maka akan mengakibatkan terkumpulnya gejala-gejala penyakit ringan hingga kronis (seperti TBC, kanker, dan lainlain) yang disebut dengan AIDS (Acquired Immunodeficiency Syndrome), yang akhirnya juga berpotensi besar pada kematian penderitanya.

Penelitian mengenai HIV/AIDS dan obatobatan untuk menanggulanginya sudah banyak dilakukan sejak virus ini pertama kali ditemukan dan diobservasi sekitar tahun 1980 di Amerika Serikat. Pengobatannya pun semakin berkembang, sehingga saat ini pengidap HIV positif sudah dapat melakukan terapi obat ARV (Antiretroviral) atau juga disebut HAART (Highly Active Antiretroviral Therapy) yang harus diminum pada waktu tertentu setiap hari seumur hidup sesuai dengan jenisnya dalam pengawasan dokter, sehingga meskipun virusnya belum dapat dimusnahkan, namun pada dasarnya replikasi HIV ini dapat dikendalikan (Scheid \& Brown, 2010). Oleh karena itu, tentunya pengobatan dan perawatan seumur hidup ini membutuhkan dukungan dari banyak pihak, seperti keluarga, teman-teman, dan lingkungan sekitar.

Meskipun pengobatan pada pengidap HIV positif sudah ditemukan, hal ini tidak serta-merta menurunkan jumlah kasus HIV dan AIDS di dunia maupun di Indonesia. Pada tahun 2006, angka pengidap HIV/AIDS yang dilaporkan oleh United Nations Programme on HIV/AIDS (UNAIDS) dan World Health Organization (WHO) sampai akhir tahun 2005 sebanyak 38,6 juta orang, dengan perkiraan 4,1 juta di antaranya merupakan pasien yang baru terinfeksi HIV dan 2,8 juta di antaranya telah meninggal dunia akibat HIV/AIDS (Orisatoki \& Oguntibeju dalam
Tadese \& Menasbo, 2013). Indonesia sendiri menduduki peringkat keempat di dunia untuk kasus penularan HIV/AIDS terbanyak (Ageng, 2013). Berdasarkan data yang dilaporkan oleh KPAP (Komisi Penanggulangan AIDS Provinsi) DKI Jakarta sampai dengan bulan Juni 2014, jumlah pengidap HIV positif di Indonesia sebanyak 142.950 orang dan jumlah pasien yang terkena AIDS sebanyak 55.623 orang. Provinsi DKI Jakarta memiliki jumlah pengidap HIV positif terbanyak yaitu 31.586 orang, diikuti oleh provinsi Papua sebanyak 15.686 orang, provinsi Jawa Timur sebanyak 18.210 orang, provinsi Jawa Barat sebanyak 12.049 orang, dan provinsi Bali sebanyak 9.051 orang.

Sementara jumlah pasien yang terkena AIDS tertinggi terdapat di provinsi Papua, yaitu sebanyak 10.184 orang, diikuti oleh provinsi Jawa Timur sebanyak 8.976 orang, provinsi DKI Jakarta sebanyak 7.477 orang, provinsi Bali sebanyak 4.261 orang, dan provinsi Jawa Barat sebanyak 4.157 orang. Selain itu, KPAP DKI Jakarta juga melaporkan peningkatan kumulatif AIDS yang terus terjadi sejak tahun 2009 hingga bulan September 2014. Meskipun demikian, KPAP DKI Jakarta mengingatkan bahwa datadata yang dilaporkan tersebut belum tentu menggambarkan jumlah keseluruhan pengidap HIV \& AIDS di Indonesia, karena sangat mungkin terdapat banyak orang yang tidak sadar dirinya sudah terinfeksi HIV dan tidak melakukan tes, atau banyak orang yang sadar perilakunya sangat berisiko terhadap penularan HIV tetapi tidak melakukan tes karena rasa takut, atau hal-hal lain yang menyebabkan tidak terdeteksinya jumlah pengidap HIV \& AIDS secara menyeluruh. Oleh karena itu, epidemiologi HIV \& AIDS ini tampak seperti fenomena gunung es.

Meskipun demikian, data yang tampak jelas secara global mengenai penularan HIV/AIDS cukup banyak terjadi di kalangan remaja usia 15-24 tahun. Data menunjukkan lebih dari $50 \%$ penularan HIV terjadi pada kelompok usia di bawah 25 tahun dengan proses penularan cukup tinggi pada kelompok seksual minoritas seperti LGBT (Lesbian, Gay, Bisexual, Transgender) yang melakukan perilaku seksual 
berisiko (CDC dalam Piperato, 2014). Usia tersebut sangat rentan terhadap proses penularan HIV/AIDS melalui hubungan seks heteroseksual yang berisiko, hubungan LSL (laki-laki yang berhubungan seks dengan laki-laki) yang berisiko, dan penggunaan jarum suntik pada remaja yang menggunakan obat-obatan terlarang (Tadese \& Menasbo, 2013). Hal ini tentu tidak terlepas dari penjelasan mengenai tahap perkembangan remaja yang merupakan fase transisi antara masa kanak-kanak menuju dewasa yang ditandai dengan perubahan perkembangan seksual primer dan sekunder, perkembangan pemikiran abstrak, peningkatan minat seksual, dan pengaruh dari teman sebaya (Santrock, 2006). Maka dari itu tidak heran apabila KPAP DKI Jakarta juga menemukan angka penularan HIV yang paling tinggi di Indonesia berada pada kisaran usia remaja, yakni usia 15-24 tahun.

Meningkatnya angka penularan HIV di dunia maupun di Indonesia tentu disebabkan oleh banyak faktor. Beberapa proses penularan HIV yang paling umum terjadi ialah perilaku seksual berisiko dengan berganti-ganti pasangan seks (baik homoseksual, heteroseksual, maupun biseksual), penggunaan jarum suntik tidak steril secara bergantian pada pengguna narkoba jarum suntik, melalui ibu yang terinfeksi HIV kepada bayinya pada saat kehamilan, persalinan, dan menyusui, serta melalui donor darah dan produk darah lainnya. Sejauh ini belum dapat ditelusuri secara pasti proses penularan yang paling banyak terjadi di Indonesia, namun terdapat informasi yang menarik ketika peneliti mengikuti pelatihan pendampingan psikologi untuk ODHA yang diselenggarakan oleh KPAP DKI Jakarta pada tahun 2014. Menurut laporan dari KPAP DKI Jakarta yang membawahi beberapa layanan VCT (Voluntary Counselling \&Testing) di area provinsi DKI Jakarta, terdapat cukup banyak ibu rumah tangga pengidap HIV positif yang tidak melakukan perilaku berisiko tertular HIV, tetapi setelah melakukan tes ternyata dinyatakan HIV positif. Terdapat kemungkinan ibu-ibu tersebut tertular HIV dari suaminya yang telah melakukan perilaku seksual berisiko dengan PSK (Pekerja Seks Komersil) atau melakukan hubungan LSL dan tidak melakukan VCT, kemudian berhubungan seksual dengan istrinya tanpa menggunakan kondom.

Selain dari proses penularan yang disebutkan di atas, stigma dan diskriminasi terhadap ODHA turut berdampak pada makin terbukanya penyebaran AIDS, karena stigma dan diskriminasi akan mematahkan semangat orang untuk berani melakukan tes dan bahkan membuat orang merasa enggan untuk mencari informasi dan cara perlindungan dari penyakit AIDS (Sosodoro, Emilia, \& Wahyuni, 2009). Beberapa literatur juga menjelaskan bahwa kekhawatiran memperoleh stigma dan diskriminasi turut mempengaruhi pengambilan keputusan ODHA untuk tidak membuka statusnya kepada siapapun (Stutterheim, Shiripinda, Bos, Pryor, de Bruin, Nellen, Kok, Prins, \& Schaalma, 2011; Stutterheim, Bos, Pryor, Brands, Liebregts, \& Schaalma, 2011). Meskipun gejala individu yang terinfeksi virus HIV belum terlalu tampak, namun ketika individu sudah terinfeksi HIV, seiring berjalannya waktu virus tersebut akan terus merusak sistem kekebalan tubuh hingga menjadi AIDS dan dapat berujung pada kematian.

Menurut Goffman (dalam Parker \& Aggleton, 2003), stigma yang khususnya berkaitan dengan isu HIV/AIDS didefinisikan sebagai atribut yang diberikan lingkungan terhadap orang atau kelompok tertentu yang secara signifikan mendiskreditkan orang tersebut hingga menurunkan 'nilainya' sebagai manusia. Lebih lanjut dijelaskan bahwa stigma yang diberikan pada kelompok yang dianggap menyimpang (seperti kelompok homoseksual, pekerja seks, pelaku kriminal, dan lainnya), akan mengarahkan pada perilaku diskriminasi terhadap kelompok tersebut. Misalnya, memberikan stigma pada semua pekerja seks sebagai individu tidak bermoral sehingga melarang mereka untuk masuk ke tempat ibadah.

Masih dari penelitian Sosodoro, Emilia, dan Wahyuni (2009), stigma yang diberikan terhadap ODHA akan berdampak pada ketidakmampuan orang untuk menunjukkan statusnya sebagai penderita HIV/AIDS. Kemunculan stigma pada masyarakat tersebut sangat berhubungan erat dengan pengetahuan 
terhadap ODHA, baik pengetahuan mengenai mekanisme penularan, perbedaan antara HIV dan AIDS itu sendiri, dan hal-hal lain terkait dengan pengetahuan mengenai HIV/AIDS. Dengan kata lain, semakin rendah tingkat pengetahuan masyarakat mengenai HIV/AIDS, maka semakin besar kemungkinan berkembangnya stigma di antara mereka (Sosodoro, Emilia, \& Wahyuni, 2009).

Peneliti juga memperoleh temuan menarik lain ketika melakukan VCT secara langsung kepada masyarakat pengunjung PRJ (Pekan Raya Jakarta) Kemayoran dalam rangka ulang tahun kota Jakarta pada bulan Juni 2015. Pengunjung memperoleh kesempatan untuk menerima konseling dan tes HIV gratis dari KPAP DKI Jakarta. Berdasarkan pengalaman peneliti yang bertindak sebagai konselor bersama beberapa konselor lain, lebih dari 50\% di antara puluhan pengunjung yang melakukan VCT mengajukan pertanyaan-pertanyaan berkaitan dengan proses penularan HIV atau pengetahuan-pengetahuan dasar yang berkaitan dengan HIV/AIDS. Beberapa pengunjung bahkan masih menanyakan apakah HIV dapat menular melalui ciuman, penggunaan handuk secara bergantian, atau makan menggunakan alat makan yang sama dengan pengidap HIV positif. Berdasarkan temuan-temuan tersebut, peneliti berasumsi terdapat kemungkinan bahwa masyarakat Jakarta pada khususnya belum memiliki pengetahuan dan pemahaman yang memadai mengenai HIV/AIDS, sehingga memiliki kecenderungan untuk menyikapi HIV/AIDS dengan kurang bijaksana. Misalnya tidak mau bersalaman dengan ODHA, mengusir anggota keluarga yang terkena HIV-positif dari rumah, atau bahkan hingga melakukan perilaku seksual berisiko.

Permasalahan stigma tersebut masih berlanjut hingga saat ini, terutama di Indonesia. Data menunjukkan bahwa dari sekitar 40 juta penduduk dunia yang telah terinfeksi HIV, lebih dari $95 \%$ berada di negara berkembang, salah satunya Indonesia (Sosodoro, Emilia, \& Wahyuni, 2009). Sejak pertama kali penyakit ini ditemukan hingga saat ini, berbagai respon seperti ketakutan, penolakan, stigma, dan diskriminasi telah muncul hingga menjadi wabah
(Sosodoro, Emilia, \& Wahyuni, 2009). Padahal jika ODHA memiliki dukungan yang sangat kuat dari lingkungan sekitarnya, terutama keluarga, hal ini akan berdampak positif pada peningkatan kualitas hidup ODHA, kepatuhannya dalam minum obat, dan kesehatan mentalnya. Sarafino (1998) sendiri menjelaskan bahwa tiap wabah penyakit tentu menimbulkan ketakutan, namun ketika pengetahuan dan pemahaman akan wabah tersebut terlalu sedikit, orang akan cenderung untuk bereaksi secara ekstrim untuk melindungi diri mereka dan orang-orang yang mereka sayangi dari wabah penyakit tersebut, termasuk salah satunya reaksi ekstrim dalam bentuk stigma. Oleh karena itu, dapat disimpulkan apabila seseorang memiliki pengetahuan dan pemahaman yang memadai mengenai suatu wabah penyakit, maka mereka akan bersikap secara wajar terhadap kemunculan maupun pencegahan wabah tersebut dan mungkin turut mempraktikkan perilaku mencegah penyebaran wabah penyakit tersebut.

Penelitian Mulu, Abera, dan Yimer (2014), menunjukkan hasil bahwa mayoritas partisipan tidak memiliki pengetahuan yang memadai mengenai HIV/AIDS, memiliki sikap yang cukup baik terhadap HIV/AIDS, namun kurang memiliki perilaku yang mengarah pada pencegahan HIV/AIDS. Mulu, Abera, dan Yimer (2014) meyakini bahwa mahasiswa memiliki risiko yang lebih besar terhadap penularan HIV/AIDS. Pengetahuan yang kurang memadai, sikap yang negatif terhadap HIV, dan perilaku seksual berisiko merupakan beberapa tantangan utama dalam mengatasi penyebaran HIV. Oleh karena itu, penelitian untuk mengetahui sejauh mana pengetahuan, sikap, dan praktik perilaku mahasiswa terhadap HIV/AIDS sangat diperlukan, khususnya di Indonesia.

Berdasarkan kamus psikologi, knowledge atau pengetahuan berarti segala pengalaman yang mencakup representasi nyata dari fakta, formula, atau situasi kompleks, beserta keyakinan kuat akan kebenaran mengenai pengalaman tersebut (Corsini, 2002). Pengetahuan mengenai HIV/AIDS berarti segala hal yang mengacu pada informasi terkait definisi, proses penularan, pencegahan, hingga pengobatan HIV/AIDS 
(Mulu, Abera, \& Yimer, 2014). Sementara attitude atau sikap merupakan kecenderungan seseorang untuk berespon baik (positif) atau tidak baik (negatif) terhadap sesuatu, orangorang tertentu, peristiwa, pemikiran, atau situasi. Sehingga dapat dikatakan sikap ialah pemikiran dan perasaan yang mendorong kita untuk bertindak seperti menyukai atau tidak menyukai sesuatu (Wortman, 1999). Sikap merupakan gabungan yang kompleks antara komponen kognitif, emosional, dan perilaku, yang berarti seseorang akan menunjukkan sikap tertentu (positif/negatif) pada suatu hal berdasarkan gabungan dari komponen pemikiran, perasaan, dan perilakunya (Weiten, 1992). Practice atau praktik di sini mengacu pada praktik perilaku yang muncul terkait dengan pencegahan HIV/AIDS atau perilaku seksual yang sehat (Mulu, Abera, \& Yimer, 2014).

\section{METODE}

Partisipan Penelitian. Total partisipan penelitian ini berjumlah 350 mahasiswa Universitas Indonesia. Teknik sampling yang digunakan adalah accidental sampling. Adapun kriteria partisipan pada penelitian ini, ialah:

1. Mahasiswa/i program diploma atau sarjana (regular/paralel/internasional) Universitas Indonesia.

2. Warga Negara Indonesia yang mampu berbahasa Indonesia.

3. Berusia antara 17-23 tahun.

4. Bersedia mengisi kuesioner yang disebarkan melalui tautan google form serta mengisi informed consent yang telah disediakan.

Alat Ukur Penelitian. Alat ukur yang digunakan pada penelitian ini berupa kuesioner KAP (Knowledge, Attitude, Practice) terstruktur online dalam format google form. Kuesioner KAP ini sudah cukup sering digunakan dalam berbagai bentuk, khususnya untuk melihat gambaran pengetahuan, sikap, dan praktik perilaku terhadap HIV/AIDS (Prybylski \& Alto, 1999; He, Zhang, Yao, Tian, Zhao, Jiang, \& Detels, 2009; Zafar, Nisar, Kadir, Fatmi, Ahmed, \& Shafique, 2014; Arora \& Sarin, 2014; Mulu,
Abera, \& Yimer, 2014). Pada penelitian ini, peneliti menggunakan kuesioner yang diadaptasi dari KAP terhadap HIV/AIDS dari Mulu, Abera, dan Yimer (2014), karena kuesioner tersebut sudah pernah diberikan kepada kelompok mahasiswa, sehingga peneliti hanya perlu melakukan adaptasi bahasa dan melakukan uji reliabilitas pada mahasiswa di Jakarta. Selain itu, jumlah aitem pada kuesioner tersebut terbilang tidak terlalu banyak dengan kalimat yang cukup mudah dipahami untuk mahasiswa.

Total aitem pada kuesioner ini berjumlah 29 pernyataan dan pertanyaan, yang terdiri dari 10 (sepuluh) pernyataan untuk mengetahui gambaran pengetahuan tentang HIV/AIDS, 8 (delapan) pernyataan untuk melihat sikap terhadap HIV/AIDS dan ODHA, serta 11 (sebelas) pernyataan untuk mengetahui praktik perilaku dalam pencegahan HIV atau perilaku seks yang sehat.

Pengetahuan mengenai HIV/AIDS berarti segala informasi yang terkait dengan definisi, proses penularan, pencegahan, hingga pengobatan dari HIV/AIDS (Mulu, Abera, \& Yimer, 2014). Sikap mengacu pada konstruk hipotetis yang menjelaskan konsistensi reaksi afektif atau perasaan seseorang terhadap suatu objek atau fenomena. Suatu sikap juga dapat diartikan sebagai suatu kesiapan seseorang untuk menunjukkan respon perilaku tertentu (DiMatteo, 1991). Sementara praktik perilaku terhadap proses pencegahan HIV/AIDS atau perilaku seks yang sehat mengacu pada segala perilaku yang menunjukkan kesadaran akan perilaku seks yang sehat atau tidak (Mulu, Abera, \& Yimer, 2014).

Prosedur Penelitian. Penelitian ini dilakukan selama enam bulan dalam rentang waktu bulan Juli hingga Desember 2015. Pada awalnya peneliti melakukan adaptasi kuesioner KAP dari Mulu, Abera, dan Yimer (2014) ke dalam bahasa Indonesia lalu melakukan expert judgment kepada tiga staf pendidik Fakultas Psikologi Universitas Indonesia pada bulan Agustus dan September 2015. Setelah itu, peneliti melakukan perbaikan terhadap beberapa aitem dan 
melakukan uji keterbacaan kepada 11 mahasiswa dari beberapa Universitas selama 2 hari di akhir bulan Oktober 2015. Setelah melakukan penyesuaian terhadap kuesioner dari hasil uji keterbacaan, peneliti melakukan uji coba kuesioner kepada 59 partisipan secara online melalui tautan http://bit.ly/kapha pada tanggal 31 Oktober 2015, yang akhirnya diperoleh hasil uji reliabilitas. Uji coba kuesioner ini menghasilkan konsistensi internal Cronbach's Alpha sebesar 0.783 , artinya alat ukur ini reliabel. Kemudian peneliti mulai melakukan proses pengambilan data mulai dari tanggal 16 November 2015 hingga 2 Desember 2015.

Proses pengambilan data diawali dengan menyebar informasi pengisian kuesioner beserta tautan aplikasi google form dari http://bit.ly/kapha melalui aplikasi pengirim pesan dan media sosial, seperti SMS (Short Messaging Service), BBM (Blackberry Messenger), Whatsapp, surat elektronik, Twitter, Path, dan lain-lain untuk memperoleh partisipan penelitian. Media-media tersebut terbilang mudah dan mampu menjaring banyak partisipan dalam waktu singkat.

Analisis Data. Data yang diperoleh dianalisis dengan teknik statistik deskriptif menggunakan bantuan software SPSS. Teknik analisis yang digunakan melalui penghitungan mean khususnya untuk melihat gambaran pengetahuan dan sikap partisipan, serta penghitungan frekuensi atau persentase untuk melihat gambaran praktik perilaku partisipan.

\section{HASIL}

Karakteristik Demografis Partisipan. Total partisipan dalam penelitian ini berjumlah 350 mahasiswa. Pada tabel berikut ini dapat dilihat gambaran data demografis partisipan yang diperoleh.
Tabel 1. Karakteristik Demografis Partisipan

\begin{tabular}{|c|c|c|c|}
\hline $\begin{array}{c}\text { Data } \\
\text { Demo- } \\
\text { grafis }\end{array}$ & Penjelasan & Frekuensi & $\begin{array}{l}\text { Persen- } \\
\text { tase }\end{array}$ \\
\hline \multirow{2}{*}{$\begin{array}{l}\text { Jenis } \\
\text { kelamin }\end{array}$} & Laki-laki & 78 & $22.3 \%$ \\
\hline & Perempuan & 272 & $77.7 \%$ \\
\hline \multirow{3}{*}{$\begin{array}{l}\text { Orientasi } \\
\text { seksual }\end{array}$} & $\begin{array}{l}\text { Homosek- } \\
\text { sual }\end{array}$ & 15 & $4.3 \%$ \\
\hline & $\begin{array}{l}\text { Heterosek- } \\
\text { sual }\end{array}$ & 317 & $90.6 \%$ \\
\hline & Biseksual & 18 & $5.1 \%$ \\
\hline \multirow{4}{*}{$\begin{array}{l}\text { Status } \\
\text { hubungan }\end{array}$} & $\begin{array}{l}\text { Tidak pernah } \\
\text { berpacaran }\end{array}$ & 79 & $22.6 \%$ \\
\hline & $\begin{array}{l}\text { Pernah } \\
\text { berpacaran } \\
\text { namun } \\
\text { sedang tidak } \\
\text { berpacaran }\end{array}$ & 139 & $39.7 \%$ \\
\hline & $\begin{array}{l}\text { Sedang } \\
\text { berpacaran }\end{array}$ & 131 & $37.4 \%$ \\
\hline & Menikah & 1 & $0.3 \%$ \\
\hline \multirow{2}{*}{$\begin{array}{l}\text { Pernah } \\
\text { berhu- } \\
\text { bungan } \\
\text { seks }\end{array}$} & $\mathrm{Ya}$ & 76 & $21.7 \%$ \\
\hline & Tidak & 274 & $78.3 \%$ \\
\hline \multirow{3}{*}{ Usia } & $\leq 18$ tahun & 41 & $11.7 \%$ \\
\hline & 19-21 tahun & 247 & $70.6 \%$ \\
\hline & $\geq 22$ tahun & 62 & $17.7 \%$ \\
\hline \multirow[b]{3}{*}{ Status HIV } & Positif & 0 & $0 \%$ \\
\hline & Negatif & 86 & $24.6 \%$ \\
\hline & $\begin{array}{l}\text { Tidak tahu } \\
\text { (belum } \\
\text { pernah tes) }\end{array}$ & 264 & $75.4 \%$ \\
\hline
\end{tabular}

Berdasarkan tabel di atas dapat dilihat bahwa partisipan yang paling banyak terlibat adalah partisipan perempuan, berusia antara 19 hingga 21 tahun, dan berorientasi heteroseksual. Status hubungan partisipan yang terlibat mayoritas pernah dan sedang menjalin hubungan berpacaran. Sekitar $21 \%$ di antaranya pernah berhubungan seksual dan sisanya mengaku belum pernah. Mengenai status HIV, 75.4\% partisipan belum pernah melakukan VCT dan tidak tahu mengenai status mereka, sementara $24.6 \%$ di antaranya mengaku berstatus negatif.

Pengetahuan Mahasiswa terhadap HIV/AIDS dan ODHA. Total pernyataan yang harus dijawab oleh partisipan berkaitan dengan pengetahuan mengenai HIV/AIDS berjumlah 10 aitem. Pernyataan-pernyataan yang ada 
merupakan pengetahuan mengenai perbedaan HIV dan AIDS, proses penularan HIV, hingga pengobatan HIV itu sendiri. Pada tabel berikut dapat dilihat beberapa contoh aitem untuk melihat gambaran pengetahuan mengenai HIV/AIDS.

\section{Tabel 2. Contoh Aitem Pengetahuan Tentang HIV/AIDS}

\begin{tabular}{l}
\hline \multicolumn{1}{c}{ Pernyataan } \\
Benar/Salah \\
Tidak ada perbedaan antara \\
HIV dan AIDS \\
AIDS ialah penyakit yang dapat \\
disembuhkan \\
Tidak berhubungan seks dengan \\
pekerja seks komersil dapat \\
mengurangi risiko penularan \\
HIV
\end{tabular}

Partisipan yang menjawab dengan benar memperoleh skor 2, sementara jika salah memperoleh skor 1. Nilai mean untuk pengetahuan terhadap HIV/AIDS ialah 1.77, sehingga untuk pernyataan yang berada di bawah nilai mean menunjukkan partisipan belum memiliki pengetahuan yang memadai di pernyataan tersebut. Dari 10 pernyataan, hanya terdapat 2 pernyataan yang memiliki nilai di bawah nilai mean, yaitu pernyataan nomor 2 ("AIDS ialah penyakit yang dapat disembuhkan") dengan nilai mean 1.19 , dan nomor 7 ("tidak berhubungan seks sama sekali merupakan salah satu cara pencegahan penularan HIV yang baik") dengan nilai mean 1.53.

Apabila dilihat secara lebih rinci, terdapat beberapa kesimpulan umum yang dapat diambil. Pertama, terdapat tujuh aitem yang mayoritas berhasil dijawab dengan benar oleh partisipan, yaitu aitem nomor $2,4,5,6,8,9$, dan 10 , di mana aitem-aitem tersebut berkaitan dengan pengetahuan mengenai penularan, pencegahan, hingga pengobatan HIV yang tepat. Kedua, terdapat dua aitem yang mayoritas dijawab dengan salah oleh partisipan, yaitu aitem nomor 1 dan 3, di mana aitem-aitem tersebut berkaitan dengan pengetahuan dasar mengenai HIV dan AIDS serta proses penularan HIV. Ketiga, terdapat satu aitem yang dijawab hampir seimbang oleh partisipan namun tetap lebih banyak yang menjawab dengan benar, yaitu aitem nomor 7 yang berkaitan dengan pencegahan penularan HIV.

Selain itu, terdapat beberapa kesimpulan khusus yang dapat diambil. Pertama, 89.7\% partisipan tidak mengetahui bahwa HIV dan AIDS itu merupakan dua hal yang berbeda. Kedua, $80 \%$ partisipan tidak mengetahui bahwa virus HIV tidak dapat ditularkan melalui berbagi makan, bertukar pakaian, dan bertukar toilet dengan ODHA. Artinya cukup banyak mahasiswa yang belum memahami bahwa proses penularan HIV bukanlah proses yang mudah, melainkan proses yang sulit karena harus ada pertukaran cairan kelamin atau darah.

Meskipun demikian, terdapat cukup banyak mahasiswa yang memiliki pengetahuan memadai mengenai proses pencegahan dan penularan HIV. Sebanyak $97.1 \%$ partisipan mengetahui bahwa luka pada alat kelamin dapat meningkatkan risiko penularan HIV ketika melakukan hubungan seks, $87.4 \%$ partisipan mengetahui bahwa tidak berhubungan seks dengan pekerja seks komersil merupakan salah satu cara pencegahan penularan HIV yang tepat, lalu $88.6 \%$ partisipan mengetahui bahwa penggunaan kondom yang benar juga merupakan salah satu cara pencegahan penularan HIV yang tepat, serta $92 \%$ partisipan juga memahami cara pencegahan penularan HIV yang lain, yaitu setia pada pasangan.

Selain itu, sebanyak $82.9 \%$ partisipan mengetahui bahwa ODHA dapat menunjukkan atau tidak menunjukkan gejala yang nyata, dan sebanyak $88.9 \%$ partisipan mengetahui pengobatan untuk ODHA bernama ARV. Mengenai pengetahuan pencegahan penularan HIV, sebanyak $53.4 \%$ partisipan mengetahui bahwa tidak berhubungan seks sama sekali merupakan salah satu cara pencegahan penularan HIV yang baik, sementara tidak demikian dengan $46.6 \%$ partisipan lainnya.

Berdasarkan hasil tersebut, dapat disimpulkan bahwa pada umumnya mahasiswa memiliki pengetahuan yang cukup baik mengenai HIV/AIDS. Mahasiswa belum 
memahami dengan baik bahwa AIDS merupakan penyakit yang tidak dapat disembuhkan dan belum memahami bahwa tidak melakukan hubungan seks sama sekali merupakan salah satu cara pencegahan penularan HIV yang baik.

\section{Sikap Mahasiswa terhadap HIV/AIDS dan}

ODHA. Total aitem untuk melihat sikap mahasiswa terhadap HIV/AIDS dan ODHA ialah 8 aitem dengan skor 2 apabila dijawab setuju dan skor 1 apabila dijawab tidak setuju untuk tiap pernyataan. Nilai mean ialah 1.75 , di mana partisipan akan dianggap memiliki sikap yang cenderung positif pada aitem nomor 2 ("sulit untuk mencegah penularan HIV") dan 4 ("penggunaan kondom ketika berhubungan seks merupakan penghinaan bagi pasangan”) jika memiliki nilai mean $<1.75$, sementara partisipan dianggap memiliki sikap yang cenderung positif pada aitem lain jika memiliki nilai mean $>1.75$.

Berdasarkan hasil yang diperoleh, aitem nomor 1 ("saya termasuk orang yang penting dalam membantu pencegahan penularan HIV") dan nomor 5 ("saya bersedia untuk tinggal satu asrama dengan mahasiswa yang terkena HIVpositif") memiliki nilai mean $<1.75$. Selain itu, aitem nomor 4 yang diprediksi memperoleh nilai mean $<1.75$ ternyata memiliki nilai mean yang sangat tinggi, yaitu 1.96. Hal tersebut menunjukkan bahwa mahasiswa belum menyadari bahwa diri mereka termasuk sosok yang sangat penting dalam membantu pencegahan penularan HIV, memiliki sikap yang negatif ketika harus tinggal berdekatan dengan orang dengan HIV-positif, dan banyak yang menyikapi penggunaan kondom merupakan penghinaan bagi pasangan. Sementara untuk 5 aitem lain mahasiswa masih menunjukkan sikap yang cenderung positif, seperti mereka menyadari bahwa meskipun mereka memiliki satu partner seks, namun penularan virus HIV mungkin dapat terjadi, serta menyadari bahwa kondom dapat diperoleh secara mudah.

Apabila dilihat secara lebih rinci, terdapat beberapa kesimpulan yang dapat diambil. Pertama, sebanyak $63.4 \%$ partisipan memiliki sikap bahwa mereka termasuk bagian yang penting dalam membantu pencegahan penularan
HIV. Kedua, seluruh partisipan (100\%) merasa bahwa risiko penularan HIV akan makin meningkat dengan berganti-ganti pasangan seks. Ketiga, sebanyak $92.3 \%$ partisipan meyakini bahwa siapapun berisiko terkena virus HIV. Keempat, sebanyak $92.6 \%$ partisipan menyadari bahwa kemungkinan penularan virus HIV tetap dapat terjadi meskipun mereka memiliki satu pasangan seks saja. Kelima, sebanyak $89.1 \%$ partisipan merasa bahwa mereka dapat memperoleh kondom dengan mudah ketika diperlukan.

Selain kesimpulan tersebut, terdapat kesimpulan lain yang sangat menarik berkaitan dengan sikap mahasiswa Universitas Indonesia terhadap HIV/AIDS. Pertama, sebanyak 64.3\% partisipan masih merasa bahwa pencegahan penularan HIV merupakan hal yang sulit, padahal cara pencegahan penularan HIV sangatlah mudah, yaitu dengan tidak melakukan hubungan seks sama sekali, menggunakan kondom ketika melakukan hubungan seksual, dan tidak bertukar jarum suntik apabila menggunakan narkotika dan obat-obatan terlarang. Kedua, sebanyak $96.3 \%$ partisipan merasa bahwa penggunaan kondom ketika berhubungan seks merupakan penghinaan bagi pasangan. Persentase tersebut terbilang tinggi dan menunjukkan kecenderungan bahwa mereka lebih memilih untuk tidak menggunakan kondom ketika melakukan hubungan seks daripada dianggap menghina pasangan. Ketiga, sebanyak $51.7 \%$ partisipan merasa enggan untuk tinggal satu asrama dengan mahasiswa yang terkena HIV-positif. Hal ini mungkin berkaitan dengan pengetahuan mereka di bagian sebelumnya mengenai proses penularan HIV, di mana terdapat cukup banyak partisipan yang meyakini bahwa penularan HIV dapat terjadi melalui berbagi makanan, bertukar pakaian, dan bertukar toilet dengan ODHA, sehingga mereka merasa enggan untuk tinggal berdekatan dengan ODHA. Meskipun demikian, $48.3 \%$ partisipan merasa tidak masalah apabila mereka harus tingggal berdekatan dengan ODHA.

Pada tabel berikut ini dapat dilihat beberapa contoh aitem untuk melihat sikap terhadap HIV/AIDS. 
Tabel 3. Contoh Aitem Sikap Terhadap HIV/AIDS

\begin{tabular}{llc}
\hline & Pernyataan & $\begin{array}{c}\text { Setuju/Tidak } \\
\text { Setuju }\end{array}$ \\
\hline $\begin{array}{l}\text { Sulit untuk mencegah } \\
\text { penularan HIV }\end{array}$ & \\
\hline
\end{tabular}

Saya termasuk orang yang

penting dalam membantu pencegahan penularan HIV

Saya bersedia untuk tinggal
satu asrama dengan
mahasiswa yang terkena HIV-
positif

Praktik Mahasiswa Terhadap HIV/AIDS. Terdapat 10 aitem mengenai praktik terhadap HIV/AIDS. Pada tabel berikut ini dapat dilihat contoh aitemnya.

\section{Tabel 4. Contoh Aitem Praktik Terhadap HIV/AIDS}

\section{Pernyataan}

Ya/Tidak

Apakah Anda merasa nyaman ketika harus memegang kondom di tangan Anda?

Apakah Anda pernah melakukan hubungan seks tanpa kondom setelah menonton film porno?

Apakah Anda pernah melakukan VCT (Voluntary Counselling and Testing) atau konseling dan tes HIV secara sukarela?

Praktik di sini terbagi menjadi dua, yaitu berkaitan dengan perilaku mahasiswa yang pernah melakukan hubungan seks dan perilaku mahasiswa yang belum pernah melakukan hubungan seks. Berdasarkan data demografis, diketahui bahwa $21.7 \%$ atau 76 partisipan sudah pernah melakukan hubungan seks vaginal maupun anal, sementara $78.3 \%$ di antaranya atau 274 partisipan belum pernah melakukan hubungan seks. Meskipun persentase partisipan yang sudah pernah melakukan hubungan seks tidak terlalu tinggi, hampir seluruhnya belum menikah (hanya 1 partisipan yang sudah menikah), sehingga dapat disimpulkan mayoritas partisipan melakukan hubungan seks bukan dengan pasangan sah (suami/istri).

Dari total 76 partisipan yang sudah pernah melakukan hubungan seks, dapat disimpulkan bahwa seluruh partisipan (100\%) yang sudah pernah melakukan hubungan seks sudah pernah melihat kondom sebelumnya, $73.7 \%$ di antaranya merasa nyaman ketika harus memegang kondom, dan $67.1 \%$ di antaranya merasa nyaman ketika mendiskusikan penggunaan kondom melalui demonstrasi. Meskipun demikian, yang mengejutkan ialah persentase partisipan dari 76 partisipan yang melakukan hubungan seksual berisiko/tanpa kondom terbilang tinggi, yaitu sebanyak $82.9 \%$. Bahkan, sebanyak $81.6 \%$ di antaranya belum pernah melakukan tes dan konseling HIV secara sukarela. Hal ini menggambarkan bahwa terdapat cukup banyak mahasiswa yang memahami penggunaan kondom, namun banyak yang rentan terkena HIV karena mereka melakukan perilaku seks berisiko dan belum pernah melakukan VCT.

Apabila dilihat lebih rinci, sekitar 35.5\% partisipan dari 76 partisipan yang ada memiliki pasangan seks lebih dari satu dan hanya 5.2\% partisipan yang pernah berhubungan seks dengan pekerja seks komersil. Jika melihat kembali data demografis partisipan yang mayoritas berada pada rentang usia dewasa muda (19-21 tahun) dan banyak di antara mereka yang pernah atau sedang berpacaran, dapat disimpulkan $82.9 \%$ partisipan yang melakukan hubungan seksual berisiko tersebut melakukannya dengan pasangan/pacar. Meskipun demikian, tetap saja hal ini menggambarkan risiko HIV yang cukup tinggi di kalangan mahasiswa.

Sementara itu, dari total 274 partisipan yang belum pernah melakukan hubungan seks, $72 \%$ di antaranya pernah melihat kondom dan $51.8 \%$ di antaranya merasa nyaman ketika mendiskusikan penggunaan kondom melalui demonstrasi. Tetapi ketika harus memegang kondom, $66.8 \%$ partisipan merasa tidak nyaman. Selain itu, $75.5 \%$ partisipan terbiasa untuk mencuci area kelamin setelah melakukan aktivitas seksual (masturbasi, dll), sehingga dapat disimpulkan bahwa cukup banyak partisipan 
yang berperilaku sehat dan higienis terhadap area kelamin mereka. Akan tetapi, hanya sekitar 3\% partisipan yang pernah melakukan VCT. Apabila melihat fakta bahwa 274 partisipan ini belum pernah melakukan hubungan seksual, angka 3\% tersebut bukanlah suatu hal yang mengkhawatirkan. Apalagi terdapat kemungkinan partisipan enggan melakukan VCT karena merasa belum pernah melakukan hubungan seksual sehingga tidak berisiko tertular HIV.

\section{SIMPULAN}

Mahasiswa memiliki pengetahuan yang cukup memadai mengenai HIV/AIDS dan ODHA, tetapi masih banyak yang belum mengetahui informasi dasar tentang HIV, AIDS, dan perbedaan antara HIV dan AIDS, serta banyak yang belum mengetahui bahwa HIV tidak dapat ditularkan melalui berbagi makanan, bertukar pakaian, dan bertukar toilet dengan orang yang positif HIV.

Mahasiswa menunjukkan sikap yang cenderung positif terhadap HIV/AIDS dan ODHA, yang artinya cukup banyak mahasiswa yang menyadari bahwa peran mereka termasuk penting dalam membantu pencegahan penularan HIV, menyadari bahwa siapapun berisiko terkena virus HIV, termasuk mereka sendiri. Tetapi yang mengejutkan ialah, cukup banyak mahasiswa yang menyikapi penggunaan kondom ketika berhubungan seks sebagai penghinaan bagi pasangan. Selain itu, cukup banyak mahasiswa yang tidak bersedia untuk tinggal berdekatan dengan ODHA yang mungkin disebabkan akibat pengetahuan yang salah mengenai penularan HIV, yaitu pemahaman bahwa HIV dapat tertular melalui berbagi makanan, bertukar pakaian, dan bertukar toilet dengan ODHA.

Mengenai praktik perilaku mahasiswa terhadap HIV/AIDS dan ODHA, cukup banyak mahasiswa yang belum pernah melakukan hubungan seks, tetapi memahami pentingnya menjaga higienitas area kelamin setelah melakukan aktivitas seksual, seperti masturbasi. Mayoritas mahasiswa enggan melakukan VCT karena mungkin merasa belum pernah melakukan hubungan seksual sehingga tidak berisiko tertular HIV.

Sementara mengenai perilaku mahasiswa terhadap HIV/AIDS dan ODHA pada mahasiswa yang sudah pernah melakukan hubungan seks terbilang cukup mengkhawatirkan. Seluruh mahasiswa yang pernah melakukan hubungan seks pernah melihat kondom, namun banyak di antara mereka yang masih melakukan perilaku seksual berisiko (tidak menggunakan kondom saat berhubungan seks). Meskipun menurut data demografis banyak di antara mereka yang pernah atau sedang berpacaran dan hanya sedikit di antara mereka yang pernah melakukan hubungan seksual dengan pekerja seks komersil, sehingga dapat disimpulkan bahwa terdapat kemungkinan mereka melakukan hubungan seks dengan pasangan mereka, namun tetap saja terdapat potensi risiko HIV di antara mereka. Apalagi banyak mahasiswa yang sudah pernah melakukan hubungan seks berisiko, tetapi tidak pernah melakukan tes dan konseling HIV secara sukarela.

Seluruh partisipan dalam penelitian ini berasal dari Universitas Indonesia. Berdasarkan hasil yang diperoleh, tentu sangatlah tidak bijak jika mengatakan bahwa hasil tersebut juga merupakan representasi dari seluruh mahasiswa di Indonesia. Sampel pada penelitian kali ini tidak dapat digeneralisasikan pada populasi mahasiswa secara keseluruhan. Oleh karena itu, akan lebih baik apabila pada penelitian berikutnya sampel yang diperoleh berasal dari Universitas yang lebih beragam sehingga dapat benar-benar mewakili populasi mahasiswa di Indonesia.

Selain itu, terdapat temuan menarik yang peneliti temukan dari proses uji keterbacaan dan proses field mengenai mahasiswa yang sudah pernah melakukan hubungan seks berisiko tetapi belum pernah melakukan VCT. Terdapat beberapa mahasiswa yang berisiko HIV, belum pernah melakukan VCT, tetapi mengaku status HIV-nya negatif. Terdapat kemungkinan mahasiswa-mahasiswa tersebut beranggapan demikian karena mereka masih berada dalam kondisi fisik yang sehat dan tidak menunjukkan 
tanda-tanda atau gejala tertentu sehingga belum perlu melakukan VCT dan meyakini bahwa status HIV mereka negatif. Hal ini tentu harus menjadi perhatian karena seseorang tidak dapat dikatakan berstatus HIV negatif apabila belum pernah melakukan VCT, apalagi jika orang tersebut sudah pernah atau sering melakukan hubungan seks berisiko meskipun dengan pasangan/pacar sendiri. Terdapat kemungkinan pasangan/pacar dari partisipan yang mengaku berstatus HIV negatif tersebut mungkin juga pernah/sering melakukan hubungan seks berisiko, sehingga secara tidak sadar sangat berpotensi untuk menularkan HIV. Mengacu pada data dari CDC (dalam Piperato, 2014), penularan HIV cukup banyak terjadi di kalangan remaja usia 15-24 tahun. Apabila mahasiswa Universitas Indonesia yang mayoritas berada pada rentang usia 19-21 tahun tetap melakukan hubungan seks berisiko dan tidak melakukan VCT, terdapat kemungkinan data dari CDC juga berlaku pada kondisi mahasiswa remaja di Indonesia. Ditambahkan pula oleh Lewis, Malow, dan Ireland (1997) yang menemukan bahwa mahasiswa pada umumnya percaya mereka tidak memiliki risiko tertular HIV dan sebagai konsekuensinya terlibat dalam perilaku seksual berisiko tinggi.

Selain itu, hal yang juga perlu menjadi perhatian serius ialah pengetahuan dasar mahasiswa mengenai proses penularan HIV yang tidak semudah berbagi makanan, bertukar pakaian, dan bertukar toilet dengan individu HIV positif. Banyak mahasiswa yang masih memiliki pemahaman keliru mengenai penularan HIV, sehingga hal ini berpotensi memicu berkembangnya stigma di masyarakat (Sosodoro, Emilia, \& Wahyuni, 2009). Bahkan dari hasil penelitian ini sendiri membuktikan bahwa lebih dari 50\% mahasiswa enggan untuk tinggal satu asrama dengan mahasiswa yang HIV positif apabila mereka diberi kesempatan. Padahal, tinggal bersama dengan ODHA tidak akan menularkan virus HIV.

Patel, Minas, Cohen, dan Prince (2014) menyatakan bahwa masalah yang muncul terhadap kelompok tertentu akibat adanya stigma, termasuk di dalamnya akibat minimnya pengetahuan, sikap, dan perilaku individu terhadap kelompok tertentu, dapat berefek sangat besar terhadap menurunnya kualitas kesehatan kelompok tersebut. Lebih lanjut dijelaskan bahwa stigma memiliki tiga elemen (Patel, Minas, Cohen, \& Prince, 2014), yaitu: (1) masalah minimnya pengetahuan karena ketidakpedulian atau perolehan informasi yang keliru; (2) minimnya pengetahuan akan mengarahkan pada masalah sikap melalui munculnya prejudice atau prasangka akibat adanya keyakinan atau opini negatif terhadap kelompok tertentu; (3) munculnya masalah perilaku dalam bentuk diskriminasi akibat adanya prasangka negatif terhadap kelompok tertentu.

Dari hasil penelitian ini, hal yang paling jelas terlihat ialah mahasiswa memiliki pengetahuan yang minim berkaitan dengan proses penularan HIV, karena cukup banyak yang menganggap bahwa HIV dapat menular melalui berbagi makanan, bertukar pakaian, dan bertukar toilet dengan orang yang HIV-positif, sehingga hal tersebut mengarahkan pada sikap yang juga negatif dan perilaku diskriminatif terhadap ODHA, yaitu dengan tidak bersedia untuk tinggal berdekatan dengan ODHA. Hal ini tentu harus menjadi perhatian bersama khususnya bagi kalangan mahasiswa agar memperoleh informasi dan pengetahuan yang lebih tepat mengenai proses penularan HIV/AIDS, sehingga tetap mampu bersikap positif dan tidak berperilaku diskriminatif terhadap ODHA.

Hal lain yang juga menarik untuk didiskusikan apabila melihat hasil penelitian ini dari sudut pandang salah satu teori klasik psikologi kesehatan, yaitu Theory of Planned Behavior (TPB). TPB meyakini bahwa sikap seseorang ditentukan oleh keyakinan individu terhadap hasil dari perilaku yang dimunculkan. Seseorang yang yakin bahwa dia akan memperoleh hasil positif jika menampilkan perilaku tertentu, maka dia turut memiliki sikap yang juga positif terhadap perilaku tersebut (Glanz, Rimer, \& Viswanath, 2008).

Hasil penelitian ini menunjukkan bahwa cukup banyak mahasiswa yang sudah pernah 
melakukan hubungan seks belum menampilkan perilaku yang sehat atau perilaku seksual berisiko, yakni melakukan hubungan seksual tanpa menggunakan kondom dan belum pernah melakukan tes dan konseling HIV secara sukarela. Menurut TPB, mahasiswa yang menunjukkan perilaku tersebut mungkin belum meyakini bahwa perilaku seksual yang sehat akan mendatangkan hasil yang positif bagi diri mereka. Keyakinan yang keliru ini tentu tidak terlepas dari pengetahuan atau informasi yang mereka peroleh, seperti menganggap bahwa jika melakukan hubungan seks sesekali tanpa menggunakan kondom masih tidak berisiko dibandingkan melakukannya dengan frekuensi yang lebih sering. Kekeliruan ini tentu harus dibenahi dengan segera melalui pemberian pengetahuan yang tepat mengenai pencegahan dan penularan HIV agar mahasiswa memiliki keyakinan bahwa perilaku seksual yang sehatlah yang justru akan membuat mereka terbebas dari penularan HIV.

\section{DAFTAR PUSTAKA}

Ageng. (2013, November). Indonesia negara urutan ke-4 penularan HIV/AIDS? Fokus Bandung Raya Online. Diunduh dari http://fokusjabar.com/2013/11/02/indone sia-negara-urutan-ke-4-penularanhivaids/.

Arora, S., \& Sarin, J. (2014). Knowledge, attitude and practices of adolescents related to HIV/AIDS in selected schools of Delhi. International Journal of Nursing Education, 6(1), 59-64.

Corsini, R. J. (2002). The dictionary of psychology. New York: Taylor \& Francis Group.

DiMatteo, M. R. (1991). The psychology of health, illness, and medical care: An individual perspective. California, USA: Brooks/Cole Publishing Company.

Glanz, K., Rimer, B. K., \& Viswanath, K. (2008). Health behavior and health education: Theory, research, and practice (4th Ed.). San Fransisco: John Wiley \& Sons, Inc.

He, N., Zhang, J., Yao, J., Tian, X., Zhao, G., Jiang, Q., \& Detels, R. (2009). Knowledge, attitudes, and practices of voluntary HIV counseling and testing among rural migrants in Shanghai, China. AIDS Education and Prevention, 21(6), 570-581.

Lewis, J. E., Malow, R. M., \& Ireland, S. J. (1997). HIV/AIDS risk in heterosexual college students: A review of a decade of literature. Journal of American College Health, 45(4), 147-158.

Mulu, W., Abera, B., \& Yimer, M. (2014). Knowledge, attitude, and practices on HIV/AIDS among students of Bahir Dar University. Science Journal of Public Health, 2(2), 78-86.

Parker, R., \& Aggleton, P. (2003). HIV and AIDS-related stigma and discrimination: A conceptual framework and implications for action. Social Science \& Medicine, 57, 13-24.

Patel, V., Minas, H., Cohen, A., \& Prince, M. J. (2014). Global mental health: Pinciples and practice. New York: Oxford University Press.

Piperato, J. M. (2014). Lesbian, gay, and bisexual college students' knowledge, perceptions, and belief about HIV/AIDS (Master's Thesis). Diunduh dari https://knowledge.library.iup.edu/cgi/vie wcontent.cgi? article $=2127 \&$ context $=$ etd

Prybylski, D., \& Alto, W. A. (1999). Knowledge, attitudes, and practices concerning HIV/AIDS among sex workers in Phnom Penh, Cambodia. AIDS Care, 11(4), 459472.

Santrock, J. W. (2006). Life-span development (10th Ed.). New York: McGraw-Hill. 
Sarafino, E. P. (1998). Health psychology: Biopsychosocial interactions (3rd Ed.). USA: John Wiley \& Sons, Inc.

Scheid, T. L., \& Brown, T. N. (2010). A handbook for the study of mental health: Social contexts, theories, and systems (2nd Ed.). USA: Cambridge University Press.

Sosodoro, O., Emilia, O., \& Wahyuni, B. (2009). Hubungan pengetahuan tentang HIV/AIDS dengan stigma orang dengan HIV/AIDS di kalangan pelajar SMA. Berita Kedokteran Masyarakat, 25(4), 210-217.

Stutterheim, S. E., Bos, A. E. R., Pryor, J. B., Brands, R., Liebregts, M., \& Schaalma, H. P. (2011). Psychological and social correlates of HIV status disclosure: The significance of stigma visibility. AIDS Education and Prevention, 23(4), 382392.

Stutterheim, S. E., Shiripinda, I., Bos, A. E. R., Pryor, J. B., de Bruin, M., Nellen, J. F. J. B., Kok, G., Prins, J. M., \& Schaalma, H. P. (2011). HIV status disclosure among HIV-positive African and AfroCarribbean people in the Netherlands. AIDS Care, 23(2), 195-205.

Tadese, A., \& Menasbo, B. (2013). Knowledge, attitude, and practice regarding HIV/AIDS among secondary school students in Mekelle City, Ethiopia. African Journal of AIDS and HIV Research, 1(1), 1-7.

Weiten, W. (1992). Psychology: Themes and variations (2nd Ed.). California: Brooks/Cole Publishing Company.

Wortman, C. B., Loftus, E. F., \& Weaver, C. (1999). Psychology (5th Ed.). USA: McGraw-Hill Companies, Inc.

Zafar, M., Nisar, N., Kadir, M., Fatmi, Z., Ahmed, Z., \& Shafique, K. (2014). Knowledge, attitude, and practices regarding HIV/AIDS among adult fishermen in coastal areas of Karachi. BMC Public Health, 14:437. 